\title{
Erratum: Cancer stem cells in melanoma
}

C Regenbrecht, Y Welte, R Hugel, U Trefzer, FO Losch, J Adjaye and P Walden ecancer 2114 (2008)

An incorrect figure was included as figure 1, please see the corrected figure below.

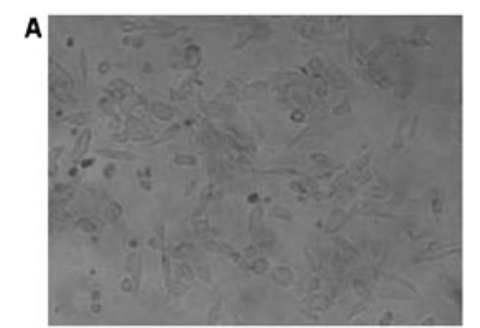

Control

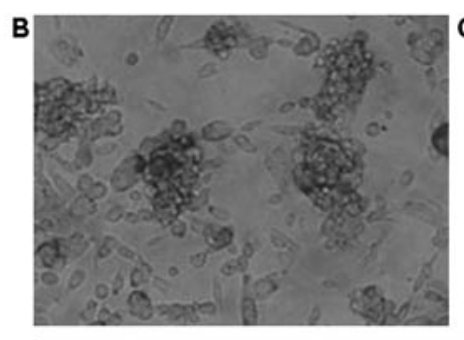

5 days

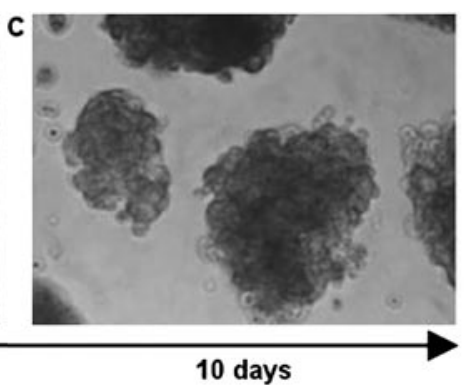

10 days

Figure 1:Change of phenotype of a melanoma cell line after cultivation in ES medium. Within ten days, originally adherent, large, elongated cells (A) formed clusters of non-adherent, small, round-shaped cells (B and C). Under ES culture condition, this phenotype remained stable for at least $\mathbf{8}$ weeks, whereas in standard medium an adherent monolayer was maintained.

Copyright: ( ) the authors; licensee ecancermedicalscience. This is an Open Access article distributed under the terms of the Creative Commons Attribution License (http://creativecommons.org/licenses/by/3.0), which permits unrestricted use, distribution, and reproduction in any medium, provided the original work is properly cited. 